\title{
Japan's Introduction from the Sea of Sei Whale Meat: the Breaking Point of CITES?
}

\author{
Erica Jayne Lyman \& Olivier Jamin
}

Correspondence: Professor of Clinical Law, International Environmental Law Project, Lewis \& Clark Law School, 10015 SW Terwilliger Blvd., Portland, OR 97219, USA. E-mail: ejt@lclark.edu

Received: June 1, 2018 Accepted: June 12, 2018 Online Published: June 22, 2018

doi:10.11114/ijlpa.v1i1.3379

URL: http://dx.doi.org/10.11114/ijlpa.v1i1.3379

\begin{abstract}
A cornerstone of the Convention on International Trade in Endangered Species of Wild Fauna and Flora (CITES) is the exertion of market control when a species' biological status is put at risk by commercial demand. This is the crux of an Appendix I listing under CITES; once a species is listed on Appendix I it may not be imported or introduced from the sea in order to be used for primarily commercial purposes. As CITES has evolved and strengthened over its forty three-year history, the Parties have agreed specific compliance measures and policy initiatives targeted toward both building upon and supporting this cornerstone. And, yet, one decision at the upcoming Standing Committee puts at risk the reputation and integrity on which CITES stands.

Since 2002 Japan has introduced from the sea sei whales and sold the meat, blubber, and other products commercially in order to raise money to support its whaling operations. Because Japan does not have a reservation for the North Pacific population of sei whale, which is listed on Appendix I, Japan's actions are in clear contravention of the Convention. The question is whether the Standing Committee is willing to hold Japan accountable for nearly 20 years of non-compliance in a demonstration of the integrity and reputation of the Convention or whether politics and power triumph.
\end{abstract}

Keywords: whaling, wildlife trade, compliance, Japan, CITES

\section{Introduction}

Sei whales (Balaenoptera borealis) are listed in Appendix I of the Convention on International Trade in Endangered Species of Wild Fauna and Flora (CITES or Convention, 1973). Since 2002, Japan has hunted sei whales on the high seas, in areas beyond the jurisdiction of any State, as part of its special permit whaling program conducted under Article VIII of the International Convention for the Regulation of Whaling. The program is now known as the "New Scientific Whale Research Program in the Western North Pacific" (NEWREP-NP) but was known as the Japanese Whale Research Program under Special Permit in the North Pacific (JARPN or JARPN II). Because sei whales are taken in the marine environment beyond the jurisdiction of any State, Japan must issue "introduction from the sea" (IFS) certificates pursuant to Article III of CITES, which prohibits introductions from the sea of specimens that will be used for "primarily commercial purposes" (CITES, 1973).

According to the CITES Trade Database and other information collected in Japan, Japan issues IFS certificates for introductions of specimens of sei whale, claiming that these introductions are for non-commercial, scientific purposes (Resolution Conf. 12.3, 2016). However, Japan does not hide the fact that the sei whale meat and other edible products are sold in both wholesale and retail marketplaces. In fact, the Institute for Cetacean Research (ICR) and other companies affiliated with whaling actively promote whale meat consumption and attempt to drive and stimulate demand for such products. The introduction from the sea by Japan of sei whale meat and other edible products that supply commercial marketplaces is currently the subject of an Article XIII CITES compliance procedure. The unfolding of this compliance issue raises several issues that have the potential to reflect on the fortitude of CITES Parties to uphold the integrity of the Convention itself and the reputation that it has as being one of the most effective multilateral environmental agreements (Johnson \& Malik, 2013).

First, it has the potential to undermine CITES' impact on the overexploitation of wildlife. Several industries rely on wild-sourced inputs, including seafood; pets, zoos, and breeding; food, medicine, and tonics; art, décor, and jewelry; cosmetics and perfume; fashion; and furniture (UNODC World Wildlife Crime Report, 2016). The ability of CITES to protect species that are threatened with extinction from commercial market demand is a cornerstone of the treaty. The 
drafters recognized the potentially negative conservation impact of wildlife-based industries and created mechanisms to protect vulnerable species from such commercialization. When a species is listed on Appendix I of CITES, the Parties have agreed that imports and introductions from the sea are prohibited when the specimen will be used for commercial purposes. If Japan's arguments prevail that it is introducing sei whale meat and other edible products for scientific purposes, the Parties are effectively endorsing a major loophole in how the "primarily commercial purposes" finding has been historically interpreted. The extent to which Japan's argument undermines the decades-long understanding of what constitutes prohibited commercial trade cannot be underestimated.

Second, because this is the first compliance procedure initiated against Japan for its activities related to whaling under CITES, which requires Parties to interpret and apply critical CITES provisions, and it is the first compliance procedure initiated against a developed country in quite a while, politics and power cast long shadows. As a result, this particular compliance procedure is a test of CITES' integrity and reputation, as opposed to the many focused on developing countries that involve a lack of enforcement capacity, of strong legislative frameworks, and of regulatory authority, which require facilitation, capacity-building, and often patience. In contrast, Japan could immediately cease introducing from the sea sei whale meat and other edible products; the question is whether the Standing Committee is willing to tell Japan that it must do so in order to come into compliance with CITES.

Third, one of Japan's central arguments pits its CITES obligations against its obligations under the ICRW. As explained more fully below, Japan argues that it must be allowed to import sei whale meat and edible products as it has done since 2002 because it would otherwise be in non-compliance with the ICRW. Although Japan's argument rests on a false premise, it raises core tenets of treaty interpretation and international law. A failure of the Standing Committee to take action against Japan could stand as tacit agreement that CITES and the ICRW are in conflict and that Japan's interpretations of its obligations prevail.

This article makes the argument that Japan is in non-compliance with the treaty but also draws specific attention to these larger issues at stake in the resolution of Japan's non-compliance. Section 2 of this article provides background on Japan's introduction from the sea of edible products of sei whale by Japan. Section 3 explores how Japan's arguments undermine CITES' object and purpose to prevent overexploitation of species due to international trade by reinterpreting the meaning of "primarily commercial purposes." Section 4 describes Japan's manipulation of the CITES compliance process, and Section 5 addresses Japan's attempt to undermine CITES requirements by falsely arguing that its obligations under the ICRW trump its CITES obligations. Viewed through these broader lenses, the importance of this particular compliance issue crystallizes. This is not a case arising from a lack of capacity or political will to tackle corruption; this case has potential impact on the integrity and reputation of CITES. Section 6 concludes that unless Japan is held accountable for its non-compliance, the Standing Committee is complicit in undermining longstanding CITES policies and the reputation CITES has built over its forty-three year history.

\section{Japan's Introduction from the Sea of Sei Whales}

From 2002-2017, Japan has hunted sei whales as part of its special permit whaling program in the North Pacific, taking 1453 sei whales (IFAW, 2017). Japan hunts sei whales in three International Whaling Commission (IWC) designated management areas - sub-areas 7, 8 and 9. Most of sub-areas 8 and 9 lay outside the jurisdiction of any State. As part of NEWREP-NP, Japan intends to take 134 sei whales annually in sub-area 8 until 2022 (Government of Japan, NEWREP-NP). Because sei whales are taken in the marine environment beyond the jurisdiction of any State, Japan must issue "introduction from the sea" (IFS) certificates pursuant to Article III of CITES, which prohibits introductions from the sea of specimens that are intended to be used for "primarily commercial purposes" (CITES, 1973).

Although Japan has issued IFS certificates, it has done so, and is continuing to do so, using purpose code " $\mathrm{S}$ " on the certificate, meaning, according to the Japanese government, that the introductions are for a scientific purpose, as opposed to a commercial purpose. However, facts undisputed by the Japanese government clearly demonstrate that the overwhelming majority of the specimens of sei whales introduced into Japan for "commercial purposes" (Memorial of Australia, 2011).

Once the whales are harpooned on the high seas, they are hauled aboard the Nisshin Maru. After measurements, such as body length, weight, and blubber thickness, are taken, the whales are butchered and divided according to type of product (Memorial of Australia, 2011). Body parts intended for research are separated from the rest of the butchered whale. Under NEWREP-NP, earplugs, eye lenses, baleen plates, plasma, and some organs are subject to scientific study (Government of Japan). Scientists conduct some biological research onboard (stomach content analysis) and the rest of the parts intended for scientific research are packaged separately for landing and transport to the Institute for Cetacean Research (ICR).

Other than the research undertaken on these small samples and body parts, ICR does not conduct scientific research on the remainder of the whale. Instead, the vast majority of each whale is packaged onboard the Nisshin Maru according to 
the type of commercially valuable product, such as red meat, white meat, skin, blubber and unesu, as well as various internal organs, including the small intestine, tongue, kidney, and heart. For ease of off-loading and distribution, the meat and the vast majority of the blubber is frozen onboard. The whale meat is frozen in $15 \mathrm{~kg}$ or smaller blocks, packaged and frozen in bags to be processed for canning, or flash-frozen in retail-friendly packaging. Based on ICR data, a sei whale yields about 12 tons of edible products. Under NEWREP-NP, the initial sampling size is 134 sei whales, which would result in approximately 1,680 tons of commercial products introduced from the sea (Sakuma, 2017).

ICR oversees the distribution and supply chain for the consumable product. According to publicly available information, prices for whale meat and blubber are set annually by the ICR (ICR, 2006). The meat is consigned to Kyodo Hanbai as ICR's sales agent in order to facilitate the sale of the whale meat to wholesalers at a fixed price set by ICR, as well as to municipalities, school boards, hospitals, fishery cooperatives, and retailers (ICR, 2006). The wholesalers who purchase whale meat from Kyodo Hanbai sell to various distributors and retailers. Kyodo Senpaku, the parent company of Kyodo Hanbai, formerly handled the sales, but Kyodo Hanbai was established in order to "improve business, including development of new products and sales channels" for whale meat (Japan Whaling Association, 2006).

\section{The Appendix I Commercial Trade Ban}

A cornerstone of CITES is the exertion of market control when a species is threatened with extinction and is or may be affected by trade. This is the crux of an Appendix I listing under CITES; once a species is listed on Appendix I it may not be imported or introduced from the sea for primarily commercial purposes. Japan makes at least two arguments in support of its introduction from the sea of sei whale meat and edible products that challenge the Parties' decades-long understanding of the "primarily commercial purposes" finding. First, it argues that because the whaling takes place as part of its special permit whaling program, i.e. scientific whaling, the introduction from the sea is for scientific purposes. Second, Japan has argued that, because the organization that applies for the introduction from the sea permits is a non-profit organization and because the sale of whale meat is not profit-making, the introduction is not for primarily commercial purposes. Both of these arguments and Japan's actions contradict and ultimately undermine one of the goals of CITES, which is to reduce demand for specimens of endangered wildlife species.

\subsection{Defining "Primarily Commercial Purposes"}

The treaty does not define "primarily commercial purposes," but the Parties have interpreted the phrase in Resolution Conf. 5.10 (Rev. CoP15). The Resolution first provides an understanding of what is meant by "commercial" and second, it clarifies how to calculate what might be a "primarily commercial purpose." Resolution Conf. 5.10 (Rev. CoP15) defines an activity as "commercial" if its purpose is to "gain economic benefit, including profit (whether in cash or in kind) . . . [when it] is directed towards resale, exchange, provision of a service or other form of economic benefit." Importing countries are to interpret the term "commercial purposes" as "broadly as possible so that any transaction which is not wholly 'non-commercial' will be regarded as 'commercial.' The resolution then provides advice to Parties regarding the determination of whether the import or introduction from the sea of a specimen will be used for "primarily commercial purposes." The resolution addresses the intended scope of "primarily" when it says that any use of imported specimens whose non-commercial aspects "do not clearly predominate shall be considered to be primarily commercial in nature."

Although CITES resolutions are not legally binding, allowing Japan to adopt a conflicting definition of "primarily commercial purposes" undermines the treaty. Article 31 of the Vienna Convention on the Law of Treaties requires treaties to be interpreted consistently with their ordinary meaning. The Oxford English Dictionary defines "commercial" as "engaged in commerce" or "of or pertaining to commerce or trade." The Dictionary also defines "commerce" as "buying or selling together; trading; exchange of merchandise." This is consistent with the understanding of Resolution Conf. 5.10 that "commercial" is about obtaining economic benefit. The Oxford English Dictionary also defines "primarily" to mean "to a great or the greatest degree; for the most part, mainly." This is also consistent with the definition provided in Resolution Conf. 5.10. Accordingly, any definition of "primarily commercial purposes" that Japan has adopted in any of its domestic measures must comport with this plain language to be in compliance with CITES.

\subsection{Taking vs. "Introducing"}

At the 69th meeting of the Standing Committee, Japan adopted the position that since the 'taking' of sei whale bodies was for a scientific purpose, the 'introduction from the sea' of the bodies could not be for "primarily commercial purposes." Japan fundamentally misconstrues the language of the Convention. Article III, paragraph 5 of the Convention requires Japan, as the State of introduction, to determine prior to issuing an IFS certificate that the specimens introduced "are not to be used for primarily commercial purposes" (CITES, 1973). This determination relates to how the specimen will be used once it has been introduced, not the reason why the specimen was taken from the wild. 
Accordingly, Japan's argument regarding the purpose of the taking is irrelevant and threatens decades of understanding regarding the "primarily commercial purposes" finding.

The Parties have historically held steadfast in their interpretation that it is the activity upon import or introduction that matters and not the nature of the activity in the country of export, or in this case, the high seas. In other words, the reason or nature of the harvest does not matter in the CITES context. For example, reptile collectors earn finders' fees and their activity is clearly commercial; however, an exotic pet collector might import a rare species for personal purposes, such as keeping it for personal enjoyment.

In fact, in the resolution defining "primarily commercial purposes," the Parties agreed that "[i]t can be assumed that a commercial transaction underlies many of the transfers of specimens of Appendix-I species from the country of export to the country of import. This does not automatically mean, however, that the specimen is to be used for primarily commercial purposes." This language clarifies that what takes place in the exporting country is separate and distinct from the use of the specimen in the country of import. In the case of introduction from the sea, this language clarifies that the nature of the take on the high seas should not be confused with the reason for the introduction. While the reason for the take may be scientific, it does not follow that the introduction will automatically be for scientific purposes.

Discussions at meetings of the Conference of the Parties have reinforced the interpretation that a "primarily commercial purposes" finding relates to the use after import or introduction. In 1997, Namibia proposed to redefine "primarily commercial purposes" to allow any conservation benefits in the country of origin resulting from trade to be considered in the determination of "primarily commercial purposes." In other words, Namibia argued that if hunting fees went to support conservation efforts, then the purpose of the import would be non-commercial. Before the proposal was withdrawn due to a lack of support, a large number of Parties objected to the proposal, emphasizing that the primarily commercial purposes finding clearly asks whether the purpose of the import or introduction is commercial, not whether the transaction in the exporting country is commercial or non-commercial.

In the case of Japan's introduction of sei whales, the issue is not whether its whaling program is commercial or scientific. Instead, the issue is the purpose for which the specimens are used upon introduction. Japan conflates these issues and suggests that it makes its primarily commercial purposes finding based on the reason for killing whales rather than the reason for the introduction. If Japan is not found in non-compliance, despite overwhelming evidence that sei whale meat and other edible products are introduced for commercial purposes, the Standing Committee is essentially reversing decades of CITES policy.

\subsection{Profit vs. Economic Benefit}

Actors involved in the Japanese whaling industry often produce materials that specifically assert that whaling is not a profitable enterprise because the money generated from the sale of whale meat is used to fund whaling operations (Rabesandratana, 2014). For example, ICR explains that "income from the sale of by-products (meat) is used to partially offset the cost of the research." Furthermore, the government of Japan has provided subsidies to both ICR and Kyodo Senpaku in order to keep the whaling enterprise afloat (EFTEC, 2009). Japan capitalizes on this to argue that its introduction of sei whales is non-commercial. However, this misconstrues the term "commercial" - the making of profit is not necessary for an activity to be considered commercial. In fact, many commercial enterprises are not profitable, yet still "commercial." For example, Amazon, the giant online retail business, did not generate profits for years (Wingfield, 2004), yet it is clearly a commercial enterprise.

Notably, the definition of "commercial" in the resolution on interpreting the primarily commercial purposes finding requires "economic benefit," not profit. In the case of Japan's whaling program, the whale meat undeniably generates economic benefit through the revenue earned from sales. The fact that sales are not enough to make the activity "profitable" for ICR is irrelevant to its commercial nature. In fact, ICR documents and regulations routinely describe the motivation for the sale of whale meat as capturing economic value for the purpose of funding scientific whaling. In other words, ICR specifically plans sales for the purpose of generating economic benefits.

Japan has also made the argument that ICR's status as a "non-profit" or "public interest corporation" means that its introduction of sei whale meat is automatically non-commercial. While ICR may not generate profits, it does sell whale meat specifically for the purpose of generating income. In fact, ICR arranges "consignment sales agreements" with for-profit corporations for the purpose of selling whale meat. Furthermore, ICR sets a fixed price for whale meat prior to distribution, highlighting that, even as a public interest corporation it has a vested commercial interest in the conduct and value of the whale meat sales.

Japan's argument that whaling is generally not profitable is not relevant to the primarily commercial purposes finding and, if implicitly endorsed, could set a strikingly dangerous precedent under CITES. If Japan's arguments stand, any business that fails to record a profit, or intentionally is not profit-making, could claim that imported wildlife is for non-commercial purposes. Using Japan's reasoning, pharmaceutical companies, exotic pet brokers, luxury brands, and 
all sorts of other businesses could import Appendix I wildlife for commercial sale simply because the business, i.e. the importer, is not turning a profit. This has the potential to completely undermine the protections CITES affords the most endangered, high-value wildlife.

\subsection{Stimulating Demand vs. Reducing Demand}

Paragraph 4 of the preamble of CITES provides that the goal of the Convention is to prevent "over-exploitation of species through international trade" (CITES, 1973). Species that are threatened with extinction-Appendix I species - are subject to "particularly strict regulation," and all international trade in those species for primarily commercial purposes is prohibited. This prohibition expresses a clear intent to prevent growth in demand for Appendix I specimens. In fact, the U.S. Secretary of the Interior, Rogers C.B. Morton, during the drafting of CITES, drew the connection explicitly for delegates, stating that " $[\mathrm{w}]$ hile many individual nations are diligently striving to protect their wildlife, the temptation of rich markets abroad continues to invite evasion of this protection" (Washington Conference, 1973). This fact remains critical to CITES implementation and the Parties are aware of the importance of demand reduction. In fact, the Parties adopted by consensus a resolution on demand reduction strategies in order to curb illegal trade in specimens (Resolution Conf. 17.4, 2017). While the circumstances of sei whale meat trade is different from the illegal poaching of other Appendix I species, such as elephants and rhinoceros, the underlying goals of the resolution are relevant here. The introduction from the sea of sei whale for the purpose of growing a domestic market directly contradicts the motivations of CITES itself and the resolution, which acknowledges that public awareness campaigns to reduce supply and demand are critical to implementation of CITES objectives.

Japan's actions with regard to sale of whale meat directly contradict the goal of demand reduction for Appendix I species, which is a cornerstone of CITES. In recent years, Japan has taken various measures aimed at growing demand in order to boost sales and make its whaling industry more profitable. For example, Kyodo Senpaku developed a plan to retrofit the Nisshin Maru, the factory ship of the whaling fleet, in order to improve the quality and marketability of whale meat. Geishoku Rabo, a company established in 2006 for the specific purpose of increasing sales of whale meat, began processing meat into pet food, and approached new industries not previously targeted for retail sales such as school lunch providers, prepared-meal providers, hospitals, universities, and the chain restaurant sector. The government of Japan endorses and even coordinates some of these activities. The Ministry of Agriculture, Forest and Fisheries runs promotional events where free samples of whale meat are distributed and the benefits of eating whale meat touted (The Age, 2006). This widespread effort to grow demand for whale meat directly contradicts CITES' goal of demand reduction, and allowing Japan to pursue these strategies undermines the credibility of the Convention.

\section{The CITES Compliance Process}

Article XIII of the Convention provides the basic process Parties follow with respect to suspected non-compliance with CITES. The Parties have further elaborated this process through a resolution, which outlines the different stages of any Article XIII compliance process (Resolution Conf. 14.3, 2007). The resolution details the specific actions that the Secretariat, Standing Committee, and relevant Parties take during each stage of a compliance procedure. Although no compliance procedure proceeds in a wholly formulaic way, the resolution intends to provide a mutually agreed progression of CITES compliance issues, in part to avoid differential treatment of Parties. For any multilateral agreement, a compliance process that is viewed as fair, equitable, transparent, and effective is essential (Tanzi \& Pitea, 2009). In many instances, treating developed and developing countries with parity is of particular concern, as developing countries often feel that compliance processes unfairly target or unfold inequitably in international environmental law (Reeve, 2002).

This particular compliance procedure involving Japan tests the integrity of CITES compliance process unlike past Article XIII compliance processes. This is the first procedure against a developed country in many years. Because it involves Japanese whaling and proactive violation of the Convention, as opposed to violations resulting from a lack of capacity, it tests the will of the Standing Committee to apply the resolution fairly and transparently. It also tests whether the Standing Committee is willing to shut down a multi-million dollar industry built on illegal trade--one that persists despite a variety of challenges in international fora. It is important to note that sei whale comprises a majority of the whale meat available in the Japanese market processed in Japan; telling Japan that it cannot legally introduce sei whales for commercial sale under CITES will fundamentally alter the Japanese whale meat market.

It is no surprise, given the stakes, that Japan is actively working to slow down the compliance process; however, allowing Japan to draw out the process and forestall its conclusion flies in the face of a fair and equitable compliance process. Of course, it also allows Japan to continue introducing sei whale. In fact, since the start of this compliance process, Japan has introduced 216 sei whales. Japan has set sail again for the north Pacific and has a catch quota for an additional 134 sei whales, for which IFS certificates have already been issued.

At the conclusion of the $69^{\text {th }}$ Standing Committee meeting in 2017, Japan sought confirmation from the Secretariat that 
it was only in the initial stages of a compliance procedure despite the fact that it was the second Standing Committee meeting at which the issue was discussed. Japan requested this confirmation during the last few hours of the week-long meeting, long after the issue was discussed by Standing Committee, during review of the daily summaries. The Secretariat confirmed Japan's position, but an analysis of the compliance process as set out in the resolution and as applied to other Parties makes clear that both the Japan and the Secretariat are incorrect. This section demonstrates that, at its next meeting, the Standing Committee must not let the position of Japan and the Secretariat prevail and instead take decisive action against Japan's non-compliance.

\subsection{Overview of the Compliance Process}

While CITES compliance often relies on a "carrot and stick" approach built around technical and financial assistance for countries lacking the necessary infrastructure to properly implement the Convention, the Conference of the Parties also developed a scheme of 'collective retorsion' to sanction non-complying States (Sand, 2017). Article XIII provides that the Secretariat shall communicate with Parties concerned when information suggests that Appendix I or II species are being adversely affected by trade in specimens of those species, or when the Convention is not being effectively implemented (CITES, 1973). However, Article XIII provides little guidance on how to address those issues, simply giving the Conference of the Parties (CoP) the authority to make "whatever recommendations it deems appropriate." In response to this lack of guidance, the CoP developed a more detailed procedure, codified in 2007 as Resolution Conf. 14.3 on Compliance and Enforcement.

The Resolution outlines a compliance process that involves four stages: (1) identification of potential compliance matters, (2) consideration of compliance matters and investigation, (3) measures to achieve compliance, and (4) monitoring and implementation of measures to achieve compliance. Each stage in the process in Resolution Conf. 14.3 is meant to be progressive so that matters are handled expeditiously and with due regard for the conservation consequences of non-compliance. At the identification stage, the Secretariat is made aware of a compliance concern and dialogue ensues with the relevant Parties. The only actors relevant at this stage are the Secretariat, the Party of concern, and any Party who has raised concerns. The Standing Committee is not involved at this stage (Resolution Conf. 14.3, 2007). In the second stage, the Standing Committee is made aware of a potential compliance issue and further investigation ensues if reason exists to believe that there might be a compliance issue at hand. In this second stage, the Standing Committee may request the Secretariat to conduct a mission on the territory of the relevant Party and report its findings to the Standing Committee at the next meeting.

Once a matter has been investigated, the Secretariat and Standing Committee have the necessary information to take action against a non-complying party. The third stage envisions various measures designed to facilitate or achieve compliance, depending on the circumstances of the compliance matter and the Party of concern (Resolution Conf. 14.3, 2007). Based on the information available, measures taken involve simple warnings to the Party that it is in non-compliance with the Convention or more aggressive measures such as recommendations to suspend trade with a Party in non-compliance (Sand, 2013). Such recommendations have recently been issued in the cases of Guinea, Lao PDR, and DRC, for example.

An important aspect of the CITES compliance process is that measures are not meant to punish Parties but rather to ensure that a Party will come into compliance as quickly as possible. Accordingly, the final stage provides for the Standing Committee and Secretariat to follow-up with respect to any recommendations made in the third stage in order for a Party to come into compliance. Generally, at each ensuing meeting of the Standing Committee, the Committee and the Secretariat assess whether the measures are still necessary or whether the Party has now come into compliance and the measures may be lifted.

\subsection{The unfolding of the compliance process regarding Japan}

Japan's insistence that the compliance procedure regarding the introduction from the sea of sei whales remains in stage one is inconsistent with the resolution on compliance and enforcement and the events that took place at the 69th meeting of the Standing Committee. Japan's manipulation of the process stands to undermine the fundamental tenets agreed by the Parties in the resolution on compliance and enforcement--namely, fairness, consistency, and transparency. Moreover, it confounds the notion that compliance matters should be handled "as quickly as possible" (Resolution Conf. 14.3, 2007).

The compliance procedure regarding the introduction of sei whale by Japan began when the European Union sent a letter to the CITES Secretariat in 2016. At that point, the Secretariat opened a dialogue with Japan, requesting that it respond to the issues raised in the letter (Summary Record SC68, 2016). The Secretariat reported this information to the Standing Committee at its 67th meeting in September 2016 and noted that it would continue to seek information from Japan and report back at the 69th meeting of the Standing Committee. Clearly, at that point the compliance process was in the first stage. 
However, the Standing Committee's actions at the 69th meeting of the Standing Committee clearly moved the process to stage two. During stage two, the Standing Committee may decide to "send back" the issue to the Secretariat for further discovery, dismiss the action, or take one of several steps, including "seek[ing] an invitation from the Party concerned" for a mission to gather further information (Resolution Conf. 14.3, 2007). This is exactly what occurred at this meeting: The Standing Committee agreed to text seeking an invitation from Japan for a technical mission. There can be no doubt that the Standing Committee's action was taken pursuant to its authority under stage two of the compliance process. It is absolutely clear that the Standing Committee did not refer the issue back to the Secretariat.

In fact, the Standing Committee amended its decision to clearly reflect that it requested a technical mission. In the decision that the Secretariat originally drafted and recommended for adoption, the Secretariat proposed that the Standing Committee task the Secretariat with communicating with Japan and consult with the Chair of the Standing Committee to determine if a technical mission would be helpful (Compliance Report, 2017). Instead, the Standing Committee adopted the following text:

The Secretariat should review the responses provided by Japan and, in consultation and cooperation with the Party concerned and the Chair of the Standing Committee, determine whether there is additional information to be considered. The Standing Committee requested the Secretariat, at the invitation of the Government of Japan, to conduct a technical mission to the country pursuant to Article XIII of the Convention.

While the Secretariat may have agreed with Japan at the end of the 69th Standing Committee meeting that Japan remains in stage one of the compliance process, this was clearly based on the decision proposed by the Secretariat and not on the decisive action by the Standing Committee.

Stage three of the compliance process provides that "if a compliance matter has not been resolved," the Standing Committee decides to take one or more measures toward compliance, including recommendations to suspend trade (Resolution Conf. 14.3, 2007). With facts already known and undisputed by Japan, and the report of the Secretariat from the mission, the Standing Committee should move without hesitation to stage three of the compliance process at its meeting in October 2018. Any other outcome would suggest bias, as the following section makes clear.

\subsection{Ensuring Fairness in the Compliance Process}

By arguing that it remains in the identification and dialogue stage of the compliance process, Japan is arguing for preferential treatment. This is an argument with which the Secretariat agreed at the last Standing Committee meeting; however, it blatantly disregards the principle of fairness in the application of the compliance process. A comparative analysis of recent compliance processes and Japan's treatment in the past when compliance concerns have been raised suggests that the Standing Committee risks reverting to past biases and outcomes. Such a result threatens the effectiveness of the compliance regime currently in place, which is emblematic of CITES' effectiveness.

The Secretariat has recently brought compliance issues before the Standing Committee involving Guinea, the Democratic Republic of the Congo (DRC), and Lao People's Democratic Republic (Lao PDR). When comparing these procedures with the compliance procedure involving Japan, it appears that the perhaps the Secretariat, and possibly the Standing Committee, may be willing to treat Japan less assertively and with less urgency. In fact, Japan has multiple times failed to submit information within the deadlines set by the Secretariat, without admonishment or consequences. And now, if Japan's arguments prevail, rendering of compliance measures will be delayed beyond the timeframe under which the compliance process has unfolded recently.

For example, the Secretariat first brought Guinea's compliance issues officially before the Standing Committee in 2011, when it noted it was in dialogue with Guinea and had requested an invitation for a mission but did not receive a response. By 2013, the Standing Committee recommended that Parties suspend all commercial trade with Guinea as a result of its failure to respond to the Secretariat and ongoing compliance concerns. The two-year timeframe represents deliberations over three Standing Committee meetings. Similarly, it took Standing Committee a two-year timeframe and two meetings to recommend a suspension of commercial trade in Siamese Rosewood with Lao PDR. With unsustainable trade in African grey parrots at stake, the compliance process moved even more swiftly as applied to the DRC. The Secretariat presented compliance concerns at the 65th meeting of the Standing Committee and at its 66th meeting, the Standing Committee recommended to suspend commercial trade in African grey parrots.

The meeting of the Standing Committee in October 2018 is the third meeting relevant to Japan's compliance procedure. Allowing this issue to continue to languish in the first or second stage of the compliance process, upon Japan's request, undermines the integrity of the compliance process and appears to set a different standard for one Party. As agreed by the Parties, accommodation in the compliance process should be provided only in those circumstances where, in a developing country, a lack of capacity and enforcement is the overriding compliance challenge. In these cases, due regard should be given to the time needed for capacity-building. In this case, however, no reason exists for extra time, and the Standing Committee is able to move forward swiftly with a decision as to whether Japan is in compliance with 
Article III of CITES.

One impetus for the adoption of the Compliance and Enforcement resolution in 2014 was to set out a clear set of guidelines in order to avoid discrepancies in application of the compliance process. A comprehensive analysis conducted in 2002 of the compliance procedures under CITES noted that

the way in which the procedure has been applied has been to some extent discriminatory, at least in the early days. Trade suspensions were recommended for easy developing country targets, while non-compliant parties such as Japan and some of the EU member states escaped (Reeve, 2002).

As noted by Dr. Reeve, Japan appears to have received special treatment in the past for non-compliance. Throughout the 1980s, many Parties raised concerns about Japan's imports of CITES-listed species. In 1985, Costa Rica and Panama complained about Japan's imports of sea turtle shells exported without appropriate documents. During a discussion of the issue at the 13th meeting of the Standing Committee, a Costa Rica representative proposed that an immediate explanation be requested of Japan and that "tak[ing] strong action" was necessary if Japan did not resolve the issue. Instead, Japan was simply informed of the Standing Committee's "deep concern" about the imports, and the issue was not raised at the next Standing Committee meeting (Reeve, 2002).

The treatment of Japan contrasts dramatically with the treatment of Thailand just a few years later: In 1991, the Standing Committee reported on Thailand's failure to implement the Convention and recommendations to suspend trade were adopted at that same meeting. The differential treatment allowed Japan to escape full compliance and any punitive measures. In fact, Japan only announced it would fully tighten import controls in 1992, and this decision was not the result of the CITES compliance process but rather in response to the U.S. decision to certify Japan under the Pelly Amendment for trade that threatened the survival of sea turtles and diminished the effectiveness of CITES.

In order to maintain the integrity and fairness of CITES and its compliance process, the Standing Committee should make a finding of non-compliance against Japan at SC70 and take appropriate measures. Any other outcome would signal a return to the early days of CITES, when developed countries could use their influence and trading power to avoid trade suspensions.

\section{The Relationship Between CITES and the ICRW}

At the $69^{\text {th }}$ meeting of the CITES Standing Committee, Japan argued that the sale of the sei whale by-products from Japan's special permit whaling is a requirement under the International Convention for the Regulation of Whaling (ICRW). As such, Japan posits that its obligation under the ICRW conflicts with CITES and that CITES cannot put Japan in the position of violating its obligations under the ICRW. Specifically, Japan argues that Article VIII(2) of the ICRW obliges Japan to sell the sei whale meat and edible products that it will not use for scientific purposes. However, the premise of the argument--that the ICRW and CITES conflict--is false. Japan's argument is inconsistent with a reading of both treaties and with well-recognized principles of international law.

\section{1 "Good Faith" and the Presumption Against Conflict}

Germane to international treaty law is the notion that Parties to treaties act "in good faith" when it comes to treaty obligations. This principle underlies the most fundamental tenets of customary international law--pacta sunt servanda, which translates to "the agreement shall be honored" and means that agreements that are legally binding must be performed. The customary international law of pacta sunt servanda is codified in Article 26 of the Vienna Convention on the Law of Treaties (VCLT): "Every treaty in force is binding upon the [P]arties to it and must be performed by them in good faith" (VCLT, 1969) Under customary law and as a Party to the VCLT, Japan is obliged to pursue its implementation of the treaties to which it is a Party in good faith and honor the treaty obligations to which it has acceded.

These tenets justify a general presumption against conflict in treaty interpretation. According to such international scholars as Grotius, interpretations are sought that provide reconciliation when provisions or terms of agreements appear to contradict (Jenks, 1953). International law is not unique in this regard; similar rules apply in the context of contract and statutory interpretation as well. Similarly, the International Court of Justice (ICJ) has stated that treaties should "be interpreted as producing and intended to produce effects in accordance with existing law and not in violation of it" (ICJ, 1957).

\subsection{No Conflict Exists Between CITES and the ICRW}

Japan's argument that Article VIII of the ICRW and Article III of CITES are in conflict belies these most fundamental tenets. Japan harvests sei whales on the high seas - outside the jurisdiction of any State - allegedly for a scientific purpose. Although Japan does appear to collect some samples for scientific research, the overwhelming majority of the bodies are then processed at sea for the purpose of sale in Japan. Japan argues that this processing and sale of the by-products is necessary under Article VIII(2). However, Article VIII(2) only imposes a duty on Parties to process the 
whales "so far as practicable":

any whales taken under [a] special permit shall so far as practicable be processed and the proceeds shall be dealt with in accordance with directions issued by the Government by which the permit was granted.

The problem with Japan's argument is that by introducing from the sea specimens of sei whale for a primarily commercial purpose, it is violating Article III of CITES. As such, Japan's action are not "practicable" because they violate Japan's obligations under CITES, which prohibits trade in sei whale specimens for primarily commercial purposes. In this case, Japan is most certainly able to comply both with its obligation under the ICRW and its obligation under CITES because the obligation deriving from Article VIII of the ICRW is qualified by practicability, which includes compliance with other treaty obligations.

No conflict exists between ICRW and CITES. Instead, flying in the face of international norms, Japan's argument seeks conflict out of convenience. International rules provide that conflict only results in cases of direct incompatibility--that is, in cases where a Party to two treaties is unable to comply simultaneously with obligations under both. Japan's suggestion that this type of conflict exists between CITES and the ICRW is pure legerdemain. Japan simply does not acknowledge the qualifying phrase "so far as practicable" out of Article VIII, paragraph 2 of the ICRW. Japan's reading is not a matter of translation or interpretation; the Japanese translation of the ICRW found on official government websites includes the phrase "so far as practicable."

Japan is distorting its understanding of CITES and ICRW in order to rationalize its desired outcome -- which is why this particular compliance process fundamentally impacts CITES' effectiveness, and broadly speaking, international law. Japan's arguments undermine CITES, subjugating core provisions of CITES to a misleading and convenient interpretation of the ICRW. Leaving Japan's game unchecked sends the message that CITES is not as effective a regime as it is purported to be because it suggests that Japanese whaling deserves special treatment.

\section{Conclusion}

Japan's introduction from the sea of sei whale meat and edible products is arguably the most important compliance procedure that has unfolded under CITES. As this article makes clear, fundamental aspects of CITES are at stake in this particular compliance procedure. These aspects, such as the prohibition of commercial trade in Appendix I specimens and an effective compliance process, are the cornerstones of CITES. Whether these CITES' cornerstones remain intact is in the Standing Committee's hands. Should any of Japan's arguments prevail, or should the Standing Committee cave to the politics of power, CITES would be open to significant re-imagination and interpretation and certainly its reputation as one of the most effective multilateral environmental agreements would be thrown into doubt.

\section{References}

Convention on International Trade in Endangered Species of Wild Fauna and Flora (CITES, 1973). 993 UNTS 243. http://www.cites.org/eng/disc/text.php

Convention on International Trade in Endangered Species of Wild Fauna and Flora. (2007). Resolution Conf. 14.3: CITES Compliance Procedures. Retrieved from https://cites.org/sites/default/files/document/E-Res-14-03.pdf

Convention on International Trade in Endangered Species of Wild Fauna and Flora. (2010). Resolution Conf. 5.10 (Rev. CoP15): Definition of 'Primarily Commercial Purposes'. Retrieved from https://cites.org/sites/default/files/document/E-Res-05-10-R15.pdf

Convention on International Trade in Endangered Species of Wild Fauna and Flora. (2016). Resolution Conf. 12.3 (Rev. CoP17): Permits and Certificates. Retrieved https://cites.org/sites/default/files/document/E-Res-12-03-R17.pdf

Convention on International Trade in Endangered Species of Wild Fauna and Flora. (2016). Sixty-Eighth Meeting of the Standing Committee: Summary Record. $\quad$ Retrieved from https://cites.org/sites/default/files/eng/com/sc/68/E-SC68-SR.pdf

Convention on International Trade in Endangered Species of Wild Fauna and Flora. (2017). Sixty-Ninth Meeting of the Standing Committee: Compliance Report. Retrieved from https://cites.org/sites/default/files/eng/com/sc/69/E-SC69-29-01-R2.pdf

Economics for the Environment Consultancy. (2009). Economics of Subsidies to Whaling. Retrieved from http://d2ouvy59p0dg6k.cloudfront.net/downloads/econ_whaling_eftec_final.pdf

Government of Japan. Research Plan for New Scientific Whale Research Program in the Western North Pacific (NEWREP-NP). Retrieved from http://www.icrwhale.org/pdf/170606newrep-np.pdf

Institute for Cetacean Research. (2006). Rules for the Processing and Sale of By-Products of the Cetacean Capture Research Program. Retrieved from https://www.legal-tools.org/doc/144e14/pdf/ 
Institute for Cetacean Research. (2006). New Organisation for Whale Meat Sales Promotion. Retrieved from https://www.legal-tools.org/doc/144e14/pdf/

International Convention for the Regulation of Whaling (ICRW, 1946). 161 UNTS 72. https://archive.iwc.int/pages/view.php?ref=3607\&k=

International Court of Justice. (1957). Rights of Passage over Indian Territory: Preliminary Objections (Portugal v. India), 1957 I.C.J. 125.

International Fund for Animal Welfare. (2017). Japan's North Pacific 'Scientific' Whaling Flouts International Law. Retrieved from https://www.ifaw.org/canada/news/japan\%E2\%80\%99s-north-pacific-\%E2\%80\%98scientific\%E2\%80\%99-whalin g-flouts-international-law

Japan Whaling Association. (2006). Japan Fisheries Agency and ICR Establish Whale Meat Retail Company, Develop New Sales Channels. Retrieved from https://www.legal-tools.org/doc/144e14/pdf/

Jenks, W. (1953). The Conflict of Law-Making Treaties. British Yearbook of International Law, 20, 40-453.

Johnson, L. \& Malik, O. (2013). CITES: 40 Years of Successful International Cooperation. Yale Center for Environmental Law \& Policy. Re http://environment.yale.edu/envirocenter/post/cites-40-years-of-successful-international-cooperation/

Memorial of Australia. (2011). Whaling in the Antarctic (Australia v. Japan). Retrieved from http://www.icj-cij.org/files/case-related/148/17382.pdf

Rabesandratana, T. (2014, March 31). Japan Ordered to Stop Scientific Whaling. ScienceMag. http://doi:10.1126/science.aac6872

Reeve, R. (2002). Policing International Trade in Endangered Species: The CITES Treaty and Compliance. The Royal Institute of International Affairs.

Sakuma, J. (2017). Report on Sei Whale Prices.

Sand, P. H. (2013). Enforcing CITES: The Rise and Fall of Trade Sanctions. Review of European, Comparative \& International Environmental Law, 22(3), 251-263. https://doi.org/10.1111/reel.12037

Sand, P. H. (2017). International Protection of Endangered Species in the Face of Wildlife Trade: Whither Conservation Diplomacy? Asia Pacific Journal of Environmental Law, 20, 5-27. https://doi.org/10.4337/apjel.2017.01.01

Tanzi, A., \& Pitela, C. (2009). Non-Compliance Procedures and Mechanisms and the Effectiveness of International Environmental Agreements (T.M.C. Asser Press, The Hague). Non-Compliance Mechanisms: Lessons Learned and the Way Forward (pp. 559-580).

The Age. (2006). Japanese Urged to Consume Whale Meat. Retrieved from https://www.theage.com.au/news/World/Japanese-urged-to-consume-whale-meat/2006/06/13/1149964509128.html

UNODC. (2016). World Wildife Crime Report: Trafficking in Protected Species. Retrieved from https://www.unodc.org/documents/data-and-analysis/wildlife/World_Wildlife_Crime_Report_2016_final.pdf

Vienna Convention on the Law of Treaties (1969). Retrieved from https://treaties.un.org/doc/publication/unts/volume\%201155/volume-1155-i-18232-english.pdf

Washington Conference. (1973). International Plenipotentiary Conference to Conclude an International Convention on Trade in Certain Species of Wildlife. Summary Record - First Plenary Session.

Wingfield, N. (2004, January 28). Amazon Reports Annual Net Profit for the First Time. Wall Street Journal.

\section{Copyrights}

Copyright for this article is retained by the author(s), with first publication rights granted to the journal.

This is an open-access article distributed under the terms and conditions of the Creative Commons Attribution License which permits unrestricted use, distribution, and reproduction in any medium, provided the original work is properly cited. 